\title{
Crural bases position as a structural criterion for supraspecific diagnosis of Early Jurassic zeilleriid brachiopods
}

\author{
José F. Baeza-Carratalá and Fernando García Joral \\ Acta Palaeontologica Polonica 59 (3), 2014: 651-661 doi: http://dx.doi.org/10.4202/app.2012.0068
}

Analysis of the internal structure carried out on several representative genera of the brachiopod family Zeilleriidae from the Lower Jurassic of the Betic Ranges (SE Spain), complemented with specimens from nearby domains such as the Iberian Range and Lusitanian Basin, has enabled to propose a model for discrimination of genera based on the relative position of the crural bases with respect to the hinge plates. This particular feature has been analysed in the genera Zeilleria, Bakonyithyris, Securina, Neozeilleria, Cincta, Aulacothyris, and Plesiothyris, revealing three different basic patterns of crural bases arrangement: a Zeilleria-type, with crural bases distinctly arising from the ventral side of the hinge plates; a Securina-type, with crural bases originating transversally to the hinge plates and dorsally prominent; and a Bakonyithyris-type, intermediate between both previous patterns.

Key words: Brachiopoda, Zeilleriidae, systematics, brachidium architecture, Jurassic, Western Tethys.

José F. Baeza Carratalá [jf.baeza@ua.es], Departamento de Ciencias de la Tierra y del Medio Ambiente, Universidad de Alicante, Campus San Vicente del Raspeig s/n, 03690, Alicante, Spain; Fernando García Joral [fgjoral@geo.ucm.es], Departamento de Paleontología, Facultad de Ciencias Geológicas. Universidad Complutense de Madrid C/ José Antonio Novais 2, 28040, Madrid, Spain.

This is an open-access article distributed under the terms of the Creative Commons Attribution License (for details please see creativecommons.org), which permits unrestricted use, distribution, and reproduction in any medium, provided the original author and source are credited. 
For Full text $(1,349.9 \mathrm{kB})$ 